\title{
Synthesis, Characterization and Antimicrobial Properties of Schiff Bases Derived from Condensation of 8-Formyl-7-hydroxy-4-methylcoumarin and Substituted Triazole Derivatives
}

\author{
KUMAR SANJEEV S. LAMANI, OBLENNAVAR KOTRESH* \\ MOHAMMEDSHAFI A. PHANIBAND and JAGANNATH C. KADAKOL \\ Department of Chemistry, \\ Karnataka Unversity's Karnatak Science College, \\ Dharwad-580001, Karnataka, India. \\ orgkotresh_org@rediff.com
}

Received 3 June 2009; Accepted 1 August 2009

\begin{abstract}
Two biologically active classes of compounds coumarins and triazoles were employed to form the Schiff bases. The synthesized Schiff base viz., 3-aryl-[(1-isocyano-4-methyl-7-hydroxycoumarin)]-5-methyl1,3,4-triazoline-2-one and its substituents were obtained by the condensation of amino group of mono and disubstituted derivatives of 3-methyl-5-oxo1,2, 4-triazoles with 8-formyl-7-hydroxy-4-methylcoumarin in alcohol. The characterization were studied by elemental analysis, IR, ${ }^{1} \mathrm{H}$ NMR and mass spectra. The biological activities of the compounds were assayed against two bacterial via, B. subtilis, E.coli and two fungal strains A. niger, C.albican. The results indicate that the present compounds may serve as better fungicides when compared to bactericides. The synthesized compounds have turned to be wonder compounds possessing antimicrobial properties.
\end{abstract}

Keywords: Coumarin, Sydnone, Schiff base, Antimicrobial.

\section{Introduction}

The structural features of meso-ionic compounds have been of interest to medicinal chemist. A wide spectrum of biological activity has been claimed for a variety of mesoionic compounds ${ }^{1}$. Their potential value as biological active substances can be explained by their dipolar structure. These rings systems are composed of delocalized electrons, which have been 
appreciably perturbed. As a result of perturbation of electrons in mesoionic system there is an oppositely charged dipolar segment at the extreme of a four atom chain. The presence of oppositely charged dipolar segment in mesoionic systems is of tremendous value to the medicinal chemist ${ }^{2}$. Its significance perhaps lies in its ability to electrostatically interact with two complementary partially charged positions on receptor macromolecule, such as a protein helix. Another structural feature of the mesoionic system is their highly charged, yet net neutral electrical character. Therefore, they are soluble to a much greater extent in non polar or lipoid solvents ${ }^{3}$. Thus in vivo, the mesoionics can cross lipid barrier even though they are internally appreciably ionic. On the contrary some quaternary salts and molecules rich in polar groups such as carbohydrates cannot pass this lipid barrier. The comparatively small size of mesoionic ring, their planar aromatic character and variation of electron density around the rings eliminates conformational problems and permitting the relatively close approach of all ring atoms to a receptor surface. Mesoionic compounds have been screened for various biological activities. In continuation of our work on synthetic biologically active sydnones ${ }^{4-5}$ and oxadiazolines $^{6}$. Novel 4-amino-2-aryl-5-methyl-2,4-dihydro-3 $H$-1,2,4-triazole-3-ones, by one pot ring conversions of 3-aryl-5-methyl-1,3,4-oxadiazoline-2-ones with hydrazine hydrate which were difficult to synthesize and were inaccessible by other methods have reported recently from our laboratory ${ }^{7}$. The prime synthetic evidence, spectral and antimicrobial studies reported from our laboratory have triggered the new routes in triazole synthetic chemistry. Schiff bases play an important role in many biochemical reactions, because of the imine linkage. Imines are to possess antibacterial and more antifungal properties.

In continuation of work, in the present investigation we focused our attention on the synthesis of 3-aryl-[(1-isocyano-4-methyl-7-hydroxy coumarin)]-5-methyl-1,3,4-triazoline2-one from 1,2,4-triazoles-3-ones and 8-formyl-7-hydroxy-4-methyl-coumarin Schiff base (Scheme 3). The aim of this work came from the observation that triazoles contain a potential free primary amino group, which could be used for variety of synthetic studies. It was interesting to study the influencing biological behaviors with various substituted triazoles. Therefore, we felt it of interest to study the chemical reactivity of these heterocyclic coumarin moieties.

\section{Experimental}

The melting points were determined by open capillaries on a Buchi-apparatus and were uncorrected. The IR spectra were recorded on a Nicolet-Impact-410 FT-IR spectrometer, using $\mathrm{KBr}$ pellets. ${ }^{1} \mathrm{HNMR}$ and ${ }^{13} \mathrm{CNMR}$ spectra were recorded on a Bruker AC-300F, $300 \mathrm{MHz}$, spectrometer in $\mathrm{CDCl}_{3}$ and $\mathrm{DMSO}-\mathrm{d}_{6}$ using TMS as an internal standard and the values are expressed in $\delta \mathrm{ppm}$. The mass spectra were recorded using EI-MS (at CRDI, Lucknow). The elemental analysis was carried out using Heraus CHN rapid analyzer. All the new compounds have given $\mathrm{CHN}$ analysis within $\pm 0.4 \%$ of the theoretical values. The homogeneity of the compounds was described by Thin Layer Chromatography on aluminum silica gel $60 \mathrm{~F}_{254}$ (merck) detected by UV light $(254 \mathrm{~nm})$ and iodine vapors. All the chemicals purchased were of analytical reagent grade, and were used without further purification unless otherwise stated.

Synthesis of 3-aryl sydnones, oxadiazolines and triazoles derivatives (With slight modification in our earlier methods ${ }^{6}$ )

The scheme is represented in Figure 1. 


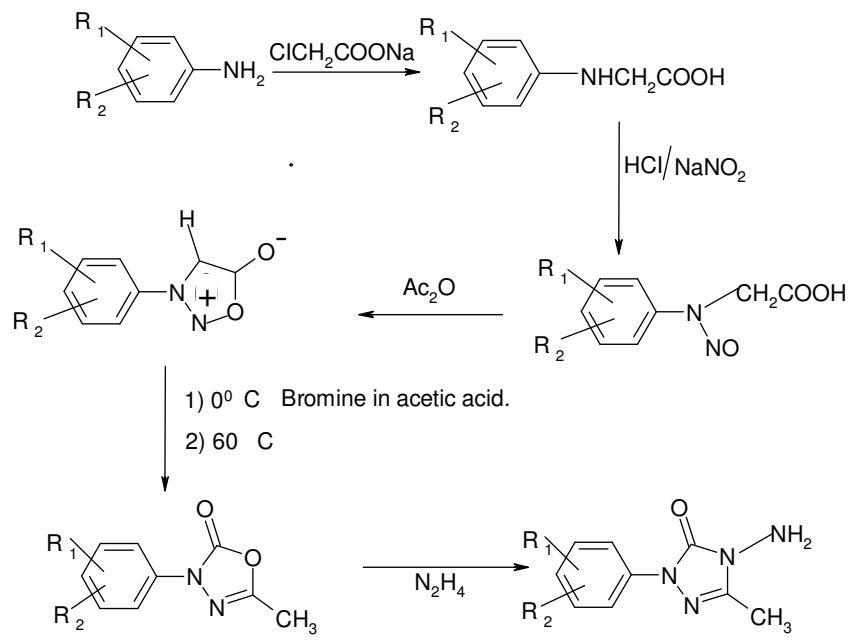

Figure 1. Systematic scheme for preparation of 3-aryl sydnones, oxadiazolines and triazoles. Synthesis of 7-hydroxy-4-methyl coumarin

A mixture of resorcinol $(0.1 \mathrm{~mol})$ and ethylacetoacetate $(0.1 \mathrm{~mol})$ in $50 \mathrm{~mL}$ sulphuric acid solution (85\%) was heated on a water bath for $3 \mathrm{~h}$. The resulting reddish brown colored solution was decomposed with $500 \mathrm{~g}$ of crushed ice. The separated bright yellow colored solid was washed with excess of cold water, dried and crystallized from methanol to get the pure product.

Dark brown crystalline solid (methanol); Yield: 80\%; m.p. $180-182{ }^{\circ} \mathrm{C}$; IR $\left(\mathrm{KBr}, \mathrm{cm}^{-1}\right)$ : $3423\left(v_{\mathrm{OH}}\right), 1733\left(v_{\mathrm{C}=\mathrm{O}}\right), 1555\left(v_{\mathrm{C}=\mathrm{C}}\right) ;{ }^{1} \mathrm{H}$ NMR $\left(300 \mathrm{MHz}, \mathrm{CDCl}_{3}+\mathrm{TFA}, \delta \mathrm{ppm}\right): 2.49$ (s, 3H, C4- $\left.\mathrm{CH}_{3}\right), 6.31(\mathrm{~s}, 1 \mathrm{H}, \mathrm{C} 3-\mathrm{H}), 6.92-6.95(\mathrm{~d}, 1 \mathrm{H}, \mathrm{C} 6-\mathrm{H}, \mathrm{J}=9 \mathrm{~Hz}), 6.94(\mathrm{~s}, 1 \mathrm{H}, \mathrm{C} 8-\mathrm{H}), 7.57-$ $760(\mathrm{~d}, 1 \mathrm{H}, \mathrm{C} 5-\mathrm{H}, \mathrm{J}=9 \mathrm{~Hz})$;

Synthesis of 8-formyl-7-hydroxy-4-methyl coumarin (I)

A mixture of 7-hydroxy-4-methyl-coumarin $(5 \mathrm{~g})$ and Hexamethylene tetramine $(10 \mathrm{~g})$ in glacial acetic acid $(40 \mathrm{~mL})$ was heated on a water bath for $6 \mathrm{~h}$. The hexamine adduct so formed was hydrolyzed with $20 \% \mathrm{HCl}(75 \mathrm{~mL})$ and the mixture was heated for another $30 \mathrm{~min}$. After cooling, the reaction mixture was extracted with diethyl ether, the ether layer was evaporated and the pale yellow colored solution was poured to crushed ice to get the pale yellow solid of 8-formyl-7-hydroxy-4-methyl coumarin which was crystallized from ethanol and dioxan mixture. The Scheme of the work is represented in Figure 2

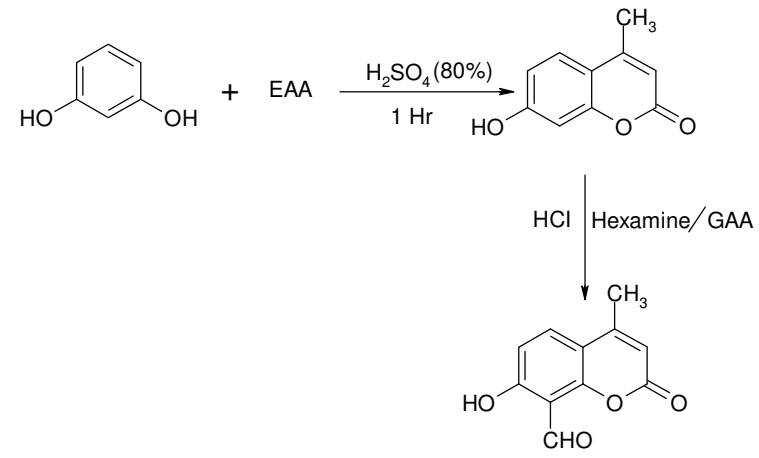

Figure 2. Systematic scheme for preparation of coumarin derivative. 
Pale yellow crystalline solid (Ethanol + dioxan); Yield: $22 \%$; m.p. $176-178{ }^{\circ} \mathrm{C}$; IR $(\mathrm{KBr}$, $\left.\mathrm{cm}^{-1}\right): 3446\left(v_{\mathrm{OH}}\right), 1742\left(v_{\mathrm{C}=\mathrm{O}}\right.$, lactone $), 1644\left(v_{\mathrm{C}=\mathrm{O}}\right.$ aldehyde), $1594\left(v_{\mathrm{C}=\mathrm{C}}\right) ;{ }^{1} \mathrm{H}$ NMR $(300 \mathrm{MHz}$, $\left.\mathrm{CDCl}_{3}, \delta \mathrm{ppm}\right): 2.44$ (s, 3H, C4-CH 3 ), $6.22(\mathrm{~s}, 1 \mathrm{H}, \mathrm{C} 3-\mathrm{H}), 6.90-6.93(\mathrm{~d}, 1 \mathrm{H}, \mathrm{C} 6-\mathrm{H}, J=9 \mathrm{~Hz})$, 7.73-7.76 (d, 1H, C5-H, J=9 Hz), 10.63 (s, 1H, HCO), 12.28 (s, 1H, OH);

Synthesis of 3-aryl-[(1-isocyano-4-methyl-7-hydroxy coumarin)]-5-methyl-1,3,4triazoline-2-one from 1,2,4-triazoles-3-ones (General procedure)

Equimolar concentrations of substituted 4-amino-2-aryl-5-methyl-2,4-dihydro-3H-1,2,4triazoles-3-ones $(0.01 \mathrm{~mol})$ and 8-formyl-7-hydroxy-4-methyl coumarin $(0.01 \mathrm{~mol})$ were stirred for $4 \mathrm{~h}$ at room temperature using alcohol as a solvent by adding a few drops of acetic acid. The solid obtained was filtered, washed with water and crystallized from ethanol. The scheme of the work is represented in Figure 3.<smiles>[R][Y]1ccc(-n2nc(C)n(N)c2=O)cc1[R]</smiles><smiles></smiles>

Figure 3. Systematic scheme for preparation of Schiff bases.

\section{Results and Discussion}

\section{Physicochemical methods}

The molecular formula of the synthesized compounds, their structural substitutions, yield in percentage, solvent used for recrystallization, melting point and the $\mathrm{C}, \mathrm{H}$ and $\mathrm{N}$ analysis with the calculated and found values are represented in Table 1.

Table 1. Elemental analysis of the compounds.

\begin{tabular}{ccccccccc}
\hline Compd & $\mathrm{R}$ & $\mathrm{R}^{\prime}$ & $\begin{array}{c}\text { M.P } \\
0\end{array}$ & $\begin{array}{c}\text { Yield, } \\
\%\end{array}$ & $\begin{array}{c}\text { Mol. } \\
\text { formula }\end{array}$ & \multicolumn{3}{c}{$\begin{array}{c}\text { Elemental analysis } \\
\text { Found (Calc), \% }\end{array}$} \\
& & & & & & $\mathrm{C}$ & $\mathrm{H}$ & $\mathrm{N}$ \\
\hline $\mathrm{I}$ & $\mathrm{H}$ & $\mathrm{H}$ & $178-79$ & 71 & $\mathrm{C}_{11} \mathrm{H}_{8} \mathrm{O}_{4}$ & $64.70(64.67)$ & $3.92(3.95)$ & $31.37(31.35)$ \\
II & $m-\mathrm{Cl}$ & $\mathrm{H}$ & $268-69$ & 65 & $\mathrm{C}_{20} \mathrm{H}_{15} \mathrm{~N}_{4} \mathrm{O}_{4} \mathrm{Cl}$ & $58.47(58.30)$ & $3.65(3.68)$ & $13.6(13.4)$ \\
III & $P-\mathrm{C} 1$ & $\mathrm{H}$ & $265-66$ & 67 & $\mathrm{C}_{20} \mathrm{H}_{15} \mathrm{~N}_{4} \mathrm{O}_{4} \mathrm{Cl}$ & $58.47(59.02)$ & $3.65(3.04)$ & $13.6(13.4)$ \\
IV & $P-\mathrm{OCH}{ }_{3}$ & $\mathrm{H}$ & $270-71$ & 66 & $\mathrm{C}_{21} \mathrm{H}_{18} \mathrm{~N}_{4} \mathrm{O}_{5}$ & $62.06(62.96)$ & $4.43(4.23)$ & $13.8(13.7)$ \\
V & $P-\mathrm{CH} \mathrm{H}_{3}$ & $\mathrm{H}$ & $256-57$ & 69 & $\mathrm{C}_{21} \mathrm{H}_{18} \mathrm{~N}_{4} \mathrm{O}_{4}$ & $64.61(64.02)$ & $4.61(4.20)$ & $14.3(14.1)$ \\
VI & $P-\mathrm{COOH}$ & $\mathrm{H}$ & $276-77$ & 71 & $\mathrm{C}_{21} \mathrm{H}_{16} \mathrm{~N}_{4} \mathrm{O}_{6}$ & $60.00(60.23)$ & $3.80(3.28)$ & $13.3(13.5)$ \\
VII & $3-\mathrm{C} 1$ & $4-\mathrm{CH}$ & $282-83$ & 82 & $\mathrm{C}_{21} \mathrm{H}_{17} \mathrm{~N}_{4} \mathrm{O}_{4} \mathrm{Cl}$ & $59.37(58.84)$ & $4.00(3.82)$ & $13.2(13.1)$ \\
VIII & $3-\mathrm{NO}_{2}$ & $4-\mathrm{C} 1$ & $275-76$ & 68 & $\mathrm{C}_{21} \mathrm{H}_{14} \mathrm{~N}_{4} \mathrm{O}_{6} \mathrm{Cl}$ & $52.69(51.92)$ & $3.07(3.24)$ & $12.3(12.2)$ \\
\hline
\end{tabular}




\section{Infrared spectra}

The IR spectra of the compounds were recorded in 4000-400 $\mathrm{cm}^{-1}$ range $\mathrm{e}^{8}$. The compounds show ${ }^{9}$ the characteristic band of $v_{(\mathrm{O}-\mathrm{H})}$ in the range $3410-3440 \mathrm{~cm}^{-1}$. The compounds exhibited bands at casually $1745 \mathrm{~cm}^{-1}$ and $1640 \mathrm{~cm}^{-1}$ for coumarin lactone carbonyl and aldehyde respectively ${ }^{10}$ and $1727 \mathrm{~cm}^{-1}$ for triazolinone. The band at $1580-1600 \mathrm{~cm}^{-1}$ are assigned to $\mathrm{v}_{(\mathrm{C}=\mathrm{C})}$ stretching ${ }^{11}$. The azomethine group being exhibited in the range $1617-1625 \mathrm{~cm}^{-1}$.

\section{${ }^{1} H$ NMR spectra}

The ${ }^{1} \mathrm{H}$ NMR spectrum of the ligand was recorded in chloroform using TMS as an internal reference. The data is given in Table 2 .

Table 2. Spectral data of the compounds.

\begin{tabular}{|c|c|c|}
\hline 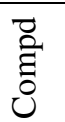 & Structure & Spectral data NMR Characterization \\
\hline I & & $\begin{array}{l}\text { IR }\left(\mathrm{KBr}, \mathrm{cm}^{-1}\right): 3446\left(v_{\mathrm{OH}}\right), 1742\left(v_{\mathrm{C}=\mathrm{O}} \text { lactone }\right), 1644 \\
\left(v_{\mathrm{C}=\mathrm{O},} \text { aldehyde), } 1594\left(v_{\mathrm{C}=\mathrm{C}}\right) ;{ }^{1} \mathrm{H} \text { NMR }(300 \mathrm{MHz}\right. \\
\left.\mathrm{CDCl}_{3}, \delta \mathrm{ppm}\right): 2.44\left(\mathrm{~s}, 3 \mathrm{H}, \mathrm{C} 4-\mathrm{CH}_{3}\right), 6.22(\mathrm{~s}, 1 \mathrm{H}, \mathrm{C} 3- \\
\mathrm{H}), 6.90-6.93(\mathrm{~d}, 1 \mathrm{H}, \mathrm{C} 6-\mathrm{H}, J=9 \mathrm{~Hz}), 7.73-7.76(\mathrm{~d}, 1 \mathrm{H}, \\
\mathrm{C} 5-\mathrm{H}, J=9 \mathrm{~Hz}), 10.63(\mathrm{~s}, 1 \mathrm{H}, \mathrm{HCO}), 12.28(\mathrm{~s}, 1 \mathrm{H}, \mathrm{OH}) ;\end{array}$ \\
\hline II & & $\begin{array}{l}\text { IR }(\mathrm{KBR}) \mathrm{cm}^{-1}: 3410\left(\mathrm{v}_{\mathrm{OH}}\right), 1745 \mathrm{~cm}^{-1} \text { (Coumarin lactone } \\
\text { carbonyl }), 1727 \mathrm{~cm}^{-1}\left(\mathrm{v}_{\mathrm{C}=\mathrm{O}} \text { of triazolinone), } 1585 \mathrm{~cm}^{-1}\right. \\
\left(\mathrm{v}_{\mathrm{C}=\mathrm{C}}\right), 1617 \mathrm{~cm}^{-1}\left(\mathrm{v}_{\mathrm{C}=\mathrm{N}}\right) .{ }^{1} \mathrm{H} \text { NMR }\left(300 \mathrm{MHz}, \mathrm{CDCl}_{3}\right): \mathrm{d} \\
(\mathrm{ppm}) 2.5(\mathrm{t}, 1 \mathrm{H}, \mathrm{CH}), 2.6\left(\mathrm{~d}, 2 \mathrm{H}, \mathrm{CH}_{2}\right), 6.8 \mathrm{e} 7.6(\mathrm{~m}, 7 \mathrm{H} \text {, } \\
\text { ArH }), \delta 2.37\left(3 \mathrm{H}, \mathrm{s}, \mathrm{CH}_{3}\right), \text { Coumarin }(\mathrm{C} 47.80 \delta \mathrm{ppm} J=9.8 \\
\mathrm{Hz}), \delta 10.0(\mathrm{~s} \text { br } 1 \mathrm{H}) \mathrm{OH} \text { Proton }\left(\mathrm{D}_{2} \mathrm{O} \text { exchanged }\right) .\end{array}$ \\
\hline III & & $\begin{array}{l}\text { IR }(\mathrm{KBR}) \mathrm{cm}^{-1}: 3430\left(\mathrm{v}_{\mathrm{OH}}\right), 1735 \mathrm{~cm}^{-1} \text { (Coumarin lactone } \\
\text { carbonyl), } 1725 \mathrm{~cm}^{-1}\left(\mathrm{v}_{\mathrm{C}=\mathrm{O}} \text { of triazolinone), } 1590 \mathrm{~cm}^{-1}\right. \\
\left(\mathrm{v}_{\mathrm{C}=\mathrm{C}}\right), 1620 \mathrm{~cm}^{-1}\left(\mathrm{v}_{\mathrm{C}=\mathrm{N}}\right) .{ }^{1} \mathrm{H} \mathrm{NMR}\left(300 \mathrm{MHz}, \mathrm{CDCl}_{3}\right): \mathrm{d} \\
(\mathrm{ppm}) 2.5(\mathrm{t}, 1 \mathrm{H}, \mathrm{CH}), 2.6(\mathrm{~d}, 2 \mathrm{H}, \mathrm{CH} 2), 6.8 \mathrm{e} 7.6(\mathrm{~m}, 7 \mathrm{H}, \\
\text { ArH }), \delta 2.37\left(3 \mathrm{H}, \mathrm{s}, \mathrm{CH}_{3}\right), \text { Coumarin }(\mathrm{C} 36.45 \delta \mathrm{ppm}, \mathrm{C} 4 \\
7.80 \delta \mathrm{ppm} J=9.8 \mathrm{~Hz} .), \delta 10.0(\mathrm{~s} \text { br } 1 \mathrm{H}) \mathrm{OH} \text { Proton }\left(\mathrm{D}_{2} \mathrm{O}\right. \\
\text { exchanged). }\end{array}$ \\
\hline IV & & $\begin{array}{l}\text { IR }(\mathrm{KBR}) \mathrm{cm}^{-1}: 3410\left(\mathrm{v}_{\mathrm{OH}}\right), 1715 \mathrm{~cm}^{-1} \text { (Coumarin lactone } \\
\text { carbonyl), } 1727 \mathrm{~cm}^{-1}\left(\mathrm{v}_{\mathrm{C}=\mathrm{O}} \text { of triazolinone }\right), 1587 \mathrm{~cm}^{-1} \\
\left(\mathrm{v}_{\mathrm{C}=\mathrm{C}}\right), 1618 \mathrm{~cm}^{-1}\left(\mathrm{v}_{\mathrm{C}=\mathrm{N}}\right) .{ }^{1} \mathrm{H} \text { NMR }\left(300 \mathrm{MHz}, \mathrm{CDCl}_{3}\right): \mathrm{d} \\
(\mathrm{ppm}) 2.5(\mathrm{t}, 1 \mathrm{H}, \mathrm{CH}), 2.6(\mathrm{~d}, 2 \mathrm{H}, \mathrm{CH} 2), 6.8 \mathrm{e} 7.6(\mathrm{~m}, 7 \mathrm{H}, \\
\text { ArH }), \delta 2.20(3 \mathrm{H}, \mathrm{s}, \mathrm{COCH} 3), \text { Coumarin }(\mathrm{C} 36.45 \delta \mathrm{ppm}, \\
\mathrm{C} 47.80 \delta \mathrm{ppm} J=9.8 \mathrm{~Hz} .), \delta 10.0(\mathrm{~s} \text { br } 1 \mathrm{H}) \mathrm{OH} \text { Proton } \\
\left(\mathrm{D}_{2} \mathrm{O} \text { exchanged). }\right.\end{array}$ \\
\hline V & & 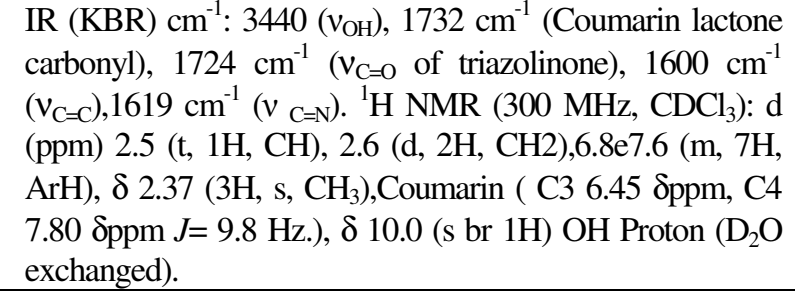 \\
\hline
\end{tabular}




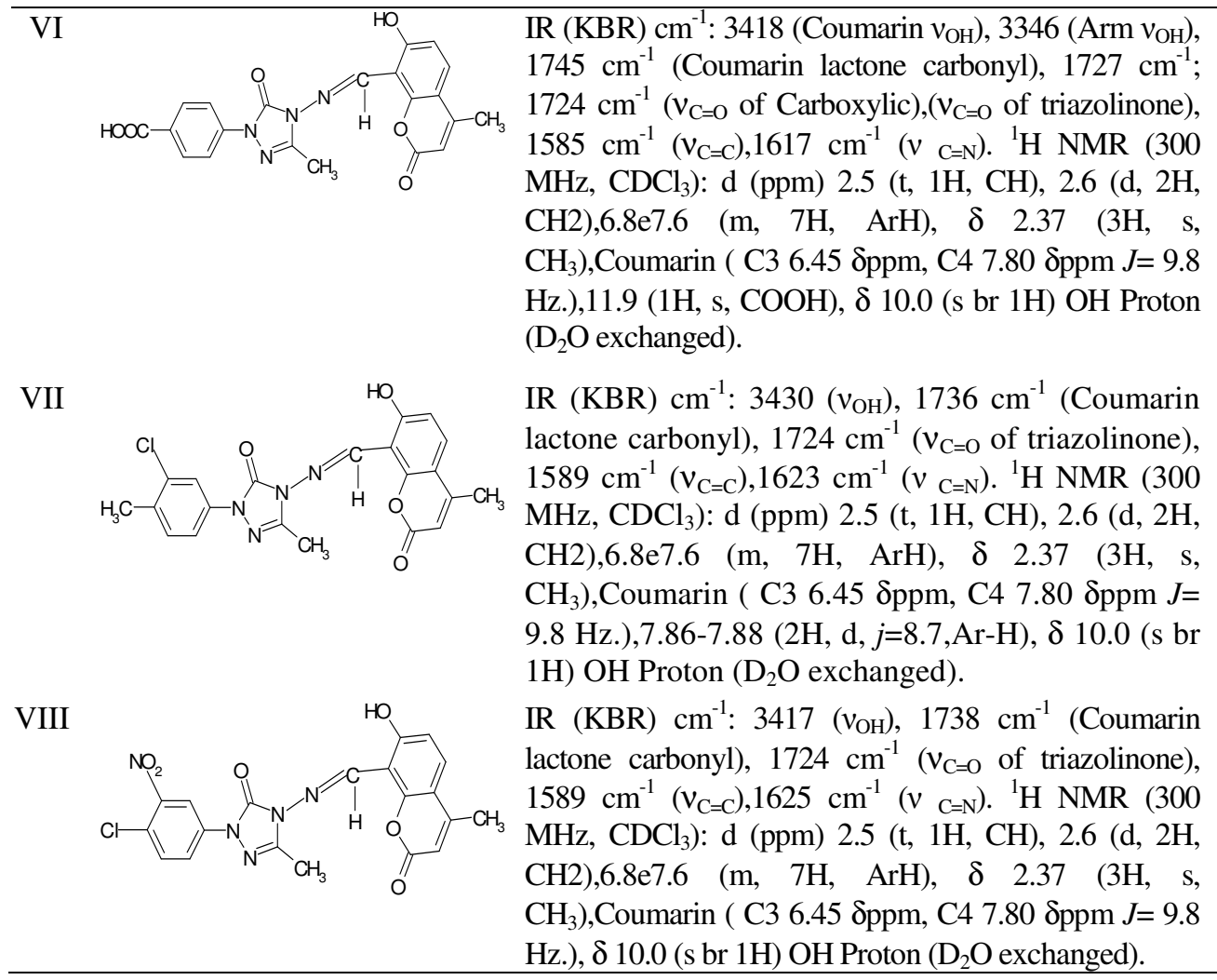

\section{Biological studies}

All the compounds were screened for their antimicrobial activity by cup plate method at 100 $\mu \mathrm{g} / \mathrm{mL}$ concentration in DMF against the Escherichia coli and B. Subtilis and also against $A$ niger and $A$. sereus fungi, using Norfloxacin and Griseofulvin as the reference drugs respectively. All these compounds were less active against the bacterial strains, but some of them showed selective fungal inhibitory activity (Table 3 ).

Table 3. Anti-microbial activities of compounds.

\begin{tabular}{ccccc}
\hline Compound & \multicolumn{2}{c}{ Antibacterial } & \multicolumn{2}{c}{ Antifungal } \\
\cline { 2 - 5 } Code & E.coli & B. subtilis & A. niger & C. Albicans \\
\hline I & 15 & 16 & 17 & 16 \\
II & 19 & 18 & 19 & 23 \\
III & 17 & 16 & 14 & 18 \\
IV & 15 & 14 & 22 & 21 \\
V & 16 & 14 & 24 & 22 \\
VI & 15 & 13 & 18 & 17 \\
VII & 14 & 14 & 17 & 18 \\
VIII & 19 & 18 & 19 & 21 \\
Norf & 22 & 22 & -- & - \\
Gris & -- & -- & 26 & 26 \\
DMF & 04 & 04 & 04 & 04 \\
\hline
\end{tabular}




\section{Conclusions}

The work has approached towards the synthetic and biological approach of these wonder molecules. Anti-bacterial property of the synthesized compounds has exhibited average inhibition, but the systematic substitution at various position and other derived compounds have shown remarkable antifungal properties. The compounds $\mathbf{2}, \mathbf{3}$ and $\mathbf{5}$ have exhibited outstanding activity towards A.niger and C. albicans the remaining compounds have shown poor antifungal activity indicating less biological importance for a synthetic chemist.

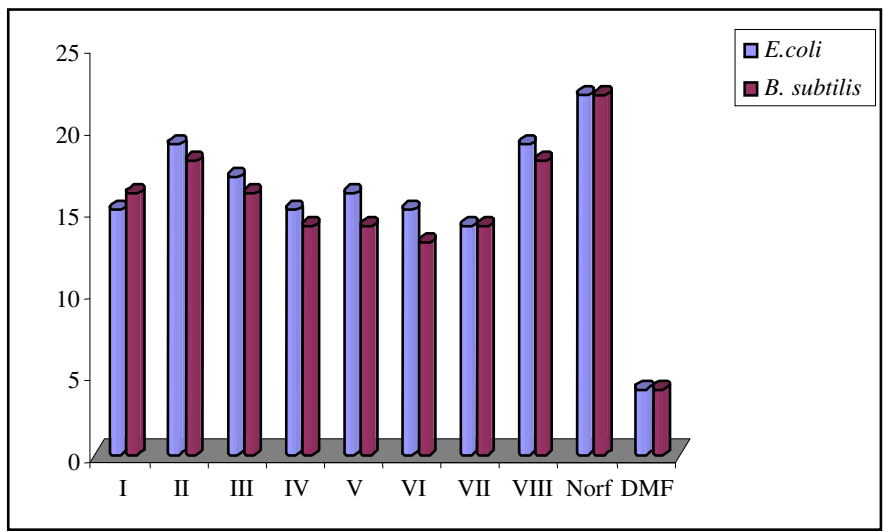

Figure 4..Antibacterial activity of Schiff bases.

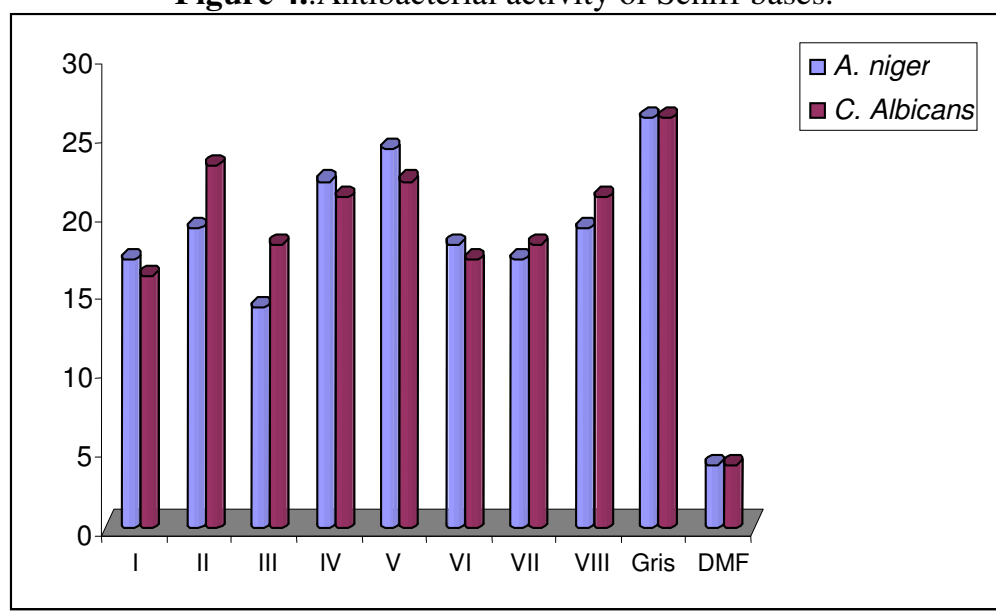

Figure 5. Antifungal activity of Schiff bases.

Efforts are under progress in evaluation of these synthesized compounds for in vivo studies especially the acute toxicity, analgesic and anti-inflammatory agents and the results will be published in later communications.

This class of compounds has a great scope compared to other organic moieties because of their mesoionic nature, solubility and high sensitiveness towards the biological behaviors.

\section{Acknowledgements}

The authors thank the University Sophisticated Instrumentation Centre, Karnatak University, Dharwad for IR and NMR facilities. Authors are also thankful to Dr. Gireesh Babu K, BioGenics, Hubli, Karnataka for his kind cooperation and useful suggestions in carrying out the microbial activities. 


\section{References}

1. Kavali J R and Badami B V, IL Farmaco, 2000, 55, 406-409.

2. Mallur S G and Badami B V, IL Farnaco, 2000, 55, 65-67.

3. Hosamani C K, Mallur S G and Badami B V, Indian J Heterocycl Chem., 1996, 6, 107.

4. Badami B V and Puranik G S, Indian J Chem., 1974, 12, 671.

5. Kavali J R, Kotresh O and Badami B V, J Chem Res (S)., 2003, 275.

6. Mohta and Kato H, In Nonbenzenoid Aromatics, Ed., Snyder J P, Academic press. New York, 1969, 117.

7. $\quad$ Earl J C and Mackney A W, J Chem Soc., 1935, 899.

8. Kametani T, Sota K and Shio M, J Heterocycl Chem., 1970, 7, 821- 829.

9. Rupe $\mathrm{H}$ and Gebhardt H, Ber, 1899, 32, 10.

10. Mallur S G and Badami B V, IL Farmaco, 2000, 55, 65.

11. Chohan Z H, Arif M, Akhar M A and Supuran C T, Bioinorganic Chemistry and Applications, 2006, 1-13. 


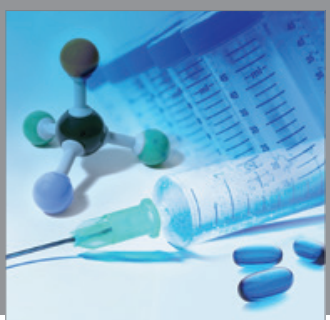

International Journal of

Medicinal Chemistry

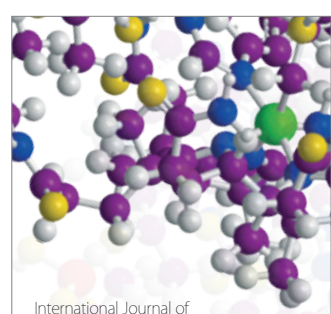

Carbohydrate Chemistry

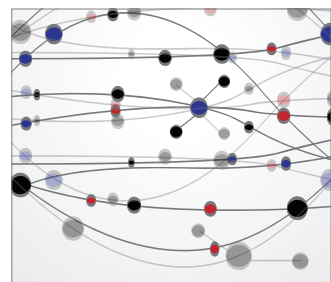

The Scientific World Journal
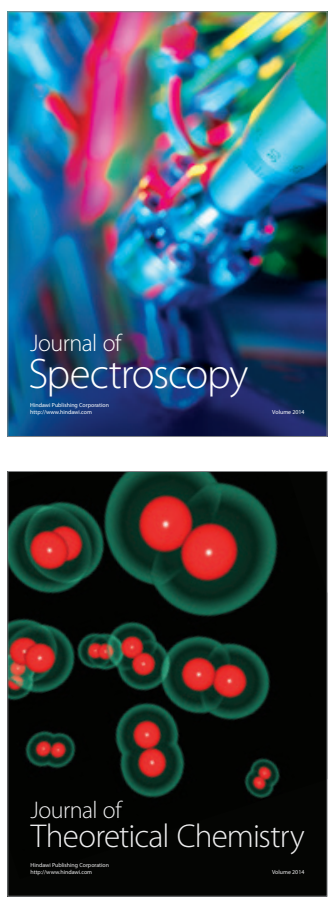
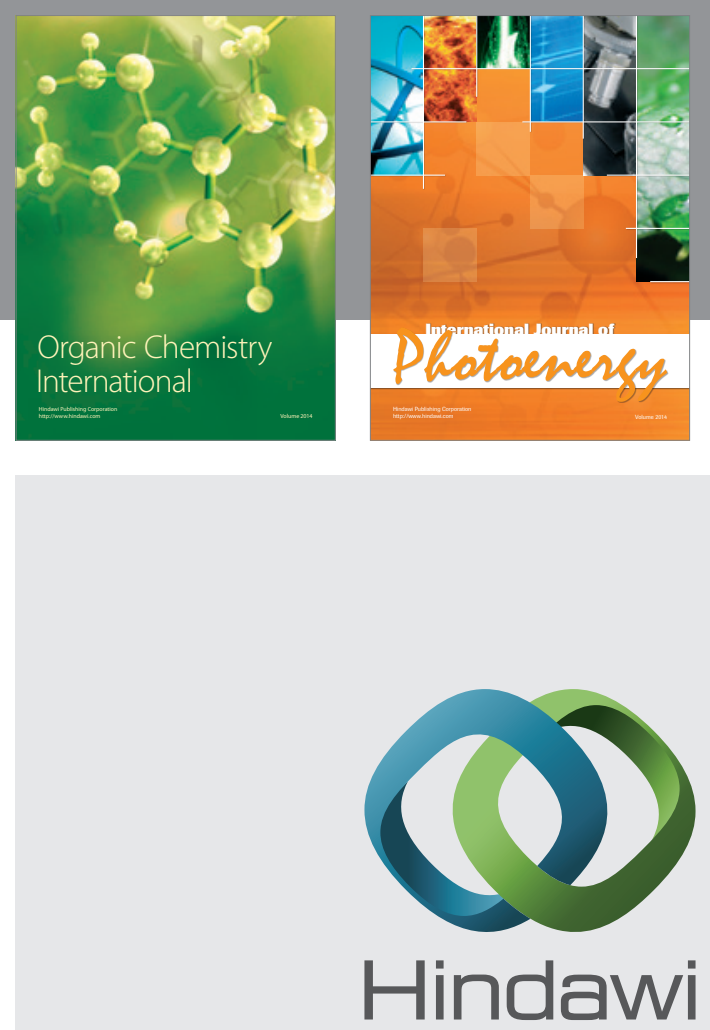

Submit your manuscripts at

http://www.hindawi.com
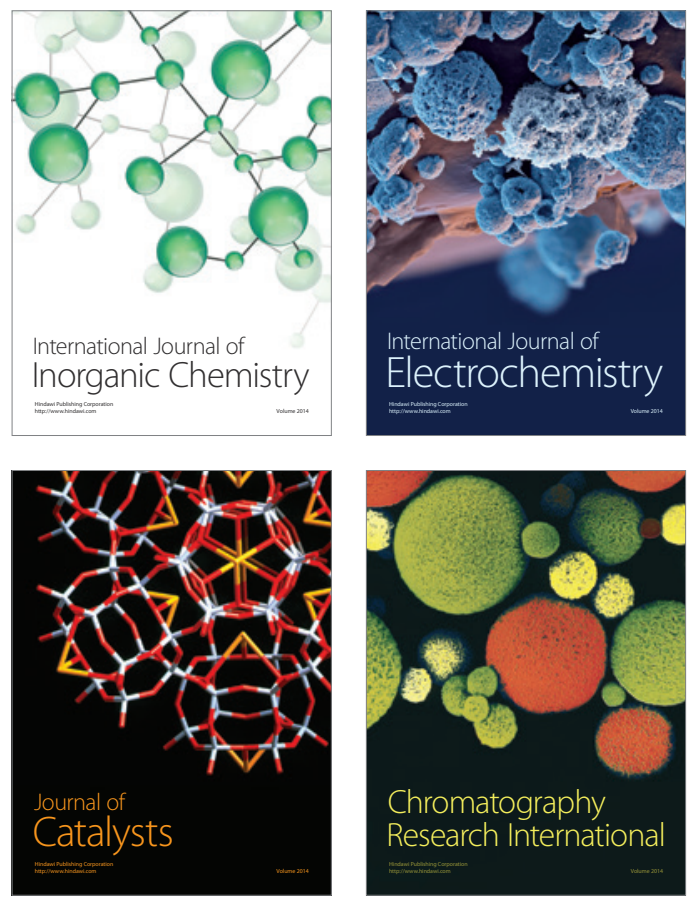
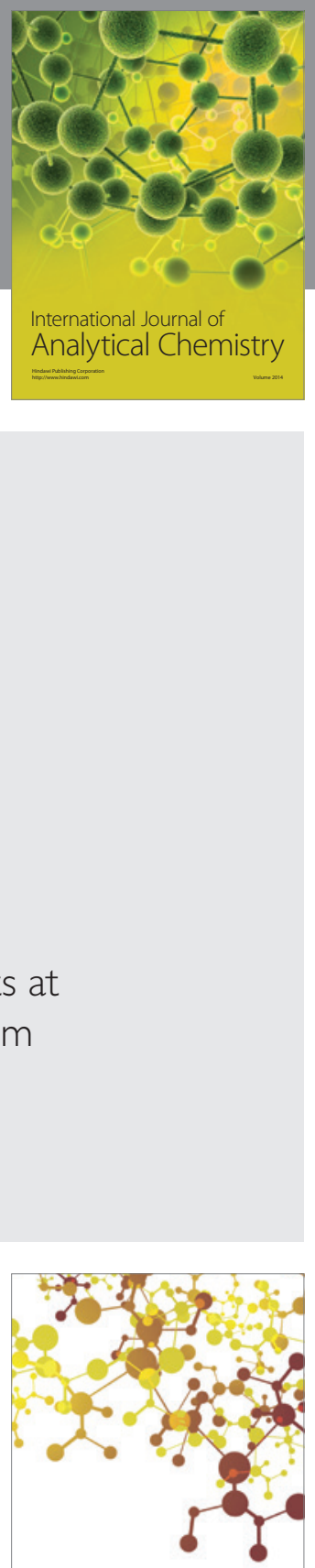

Journal of

Applied Chemistry
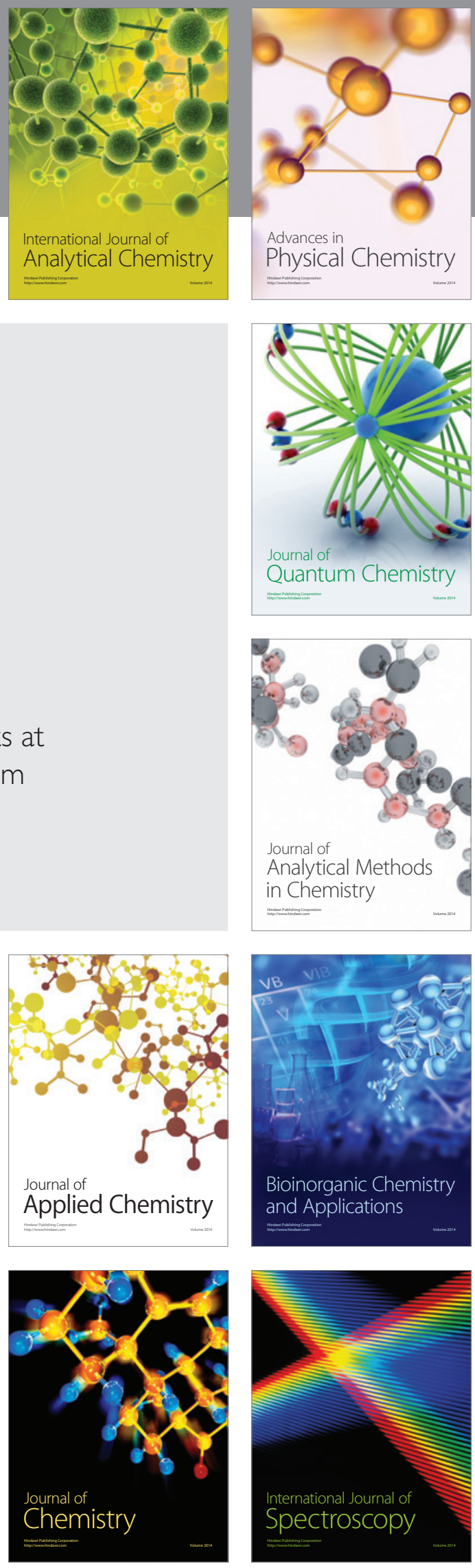